I. О. Крицький, П. В. Гощинський, Т. І. Крицький, І. М. Горішній, О. М. Мочульська, Г. А. Крицька

ДВНЗ “Тернопільський державний медичний університет імені І. Я. Горбачевського МОЗ України”

\title{
ФОРМУВАННЯ ПРОФЕСІЙНОЇ КОМПЕТЕНТНОСТІ МАЙБУТНЬОГО ЛІКАРЯ НА ПРИКЛАДІ СТУДЕНТІВ МЕДИЧНОГО ФАКУЛЬТЕТУ ТДМУ
}

\author{
I. O. Krytskyi, P. V. Hoshchynskyi, T. I. Krytskyi, I. M. Horishnyi, \\ O. M. Mochulska, H. A. Krytska \\ I. Horbachevsky Ternopil State Medical University
}

\section{FORMATION OF THE PROFESSIONAL COMPETENCE OF THE FUTURE DOCTOR AT THE EXAMPLE OF STUDENTS OF THE MEDICAL FACULTY IN TSMU}

\begin{abstract}
Мета роботи - оцінити значення професійної компетентності студентів, формування критеріїв оцінювання їх досягнень, готовності до майбутньої діяльності лікаря.

Основна частина. У нашому дослідженні необхідно з'ясувати змістове наповнення поняття “професійна компетентність майбутнього лікаря”. Аналіз змісту визначень понять “компетентність” і “компетенція” доводить нас до розуміння сутності цих понять, яке важливе для побудови моделі компетентного випускника вищого медичного навчального закладу, формування критеріїв оцінювання досягнень студентів, їх готовності до майбутньої діяльності лікаря. Формування професійної компетентності у контексті психології особистості становлення майбутнього лікаря потребує обгрунтування інтегрованої моделі та вдосконалення змісту, структури, форм і методів професійної підготовки студентів до виконання лікарської діяльності, визначення психолого-педагогічних умов підвищення професійної компетентності. Теоретичний аналіз дозволив нам використати модель і включити у неї всі необхідні, на нашу думку, фахові якості, які є складовими компонентами професійної компетентності майбутнього лікаря.

Висновок. Представлені нами матеріали професійної компетентності майбутнього лікаря - це важлива складова теоретичної і практичної підготовленості студента на основі особистих і професійно важливих якостей; стан сформованості професійних знань, умінь та навичок, необхідних для виконання діяльності лікаря в майбутньому.
\end{abstract}

Ключові слова: студент; професійна компетентність; ефективність; майбутній лікар.

The aim of the work - to assess the value of students' professional competence, the formation of criteria for evaluating their achievements, and readiness for future medical activities.

The main body. In our study, it is necessary to find out the content of the concept of "professional competence of the future doctor". The analysis of the content of definitions of the concepts of "competence" and "competence" leads us to an understanding of the essence of these concepts, which is important for the construction of a model of a competent graduate of a higher medical school, the formation of criteria for assessing the achievements of students, their readiness for future activities of the doctor. Formation of professional competence in the context of the psychology of personality of the future physician's formation requires the substantiation of the integrated model and improvement of the content, structure, forms and methods of professional training of students for the implementation of medical activities, definition of psychological and pedagogical conditions for improving professional competence. The theoretical analysis allowed us to use the model and include in it all necessary, in our opinion, professional qualities as components of the professional competence of the future doctor.

Conclusion. The materials of professional competence of the future doctor presented by us are an important component of the theoretical and practical preparation of the student on the basis of personal and professional qualities; the state of the formation of the professional knowledge, skills and skills necessary for the doctor's future work.

Key words: student; professional competence; efficiency; future doctor.

Вступ. Вища медична освіта повинна забезпечити високоякісну підготовку студентів і є важливою

(c) I. О. Крицький, П. В. Гощинський, Т. І. Крицький та ін. складовою реформування галузі охорони здоров’я та реалізації соціальних пріоритетів держави, оскільки від рівня підготовки майбутніх лікарів 
залежить якість надання медичної допомоги населенню країни [1, 2]. Сучасне суспільство розглядає фахівця не лише як людину, яка володіє знаннями, уміннями і навичками у професійній сфері, але і як людину, здатну ефективно діяти у складних, нестандартних ситуаціях, самостійно приймати рішення, творчо розвиватися і самовдосконалюватися, сповідувати толерантне ставлення до оточуючих, уміти спілкуватися з людьми [3, 4]. Ці та інші професійно важливі властивості та особисті якості визначають професійну компетентність спеціаліста [2, 3]. Сьогодення і майбутнє світової та вітчизняної професійної медичної освіти потребують вдосконалення науково-теоретичної і практичної підготовки майбутніх фахівців [1, 5]. Сучасність вимагає виховання самостійних, ініціативних і відповідальних членів суспільства, здатних ефективно взаємодіяти у вирішенні соціальних, професійних та економічних завдань як на національному, так і на міжнародному рівні [1, 6, 7].

Мета роботи - оцінити значення професійної компетентності студентів, формування критеріїв оцінювання їх досягнень, готовності до майбутньої діяльності лікаря.

Основна частина. Враховуючи специфіку професійної діяльності лікаря, його професійна компетентність базується на ключових навичках, а саме: професійних, комунікативних, дослідницьких та наукових [3, 5, 6]. Формування професійної компетентності в контексті психології особистості становлення майбутнього лікаря потребує обгрунтування інтегрованої моделі та вдосконалення змісту, структури, форм і методів професійної підготовки студентів до виконання лікарської діяльності, визначення психолого-педагогічних умов підвищення професійної компетентності [3, 6]. Теоретичний аналіз дозволив нам використати модель і включити у неї всі необхідні, на нашу думку, фахові якості, які є складовими компонентами професійної компетентності майбутнього лікаря [4]. Модель є складним утворенням, що включає два блоки взаємопов'язаних багатофункціональних компонентів [1, 5, 7]:

1) блок компонент професійної компетентності;

2) блок психолого-педагогічних умов забезпечення формування професійної компетентності.

Блок компонент професійної компетентності мікромодель, яка відображає прогнозований кінцевий результат професійної підготовки студента професійну компетентність майбутнього лікаря [3, 4, 7]. Застосування наукових підходів до становлення особистості та відповідної професійної підготовки майбутнього лікаря дозволило нам розробити механізм розвитку професійної компетентності, визначити компетентності та компетенції майбутнього лікаря, розробити мікромодель здійснення процесу формування професійної компетентності [5-7]. За твердженням I. Беха, керівництво формуванням професійної компетентності тільки тоді може дати позитивний результат, коли воно впливатиме на особистість не прямо, а через розгортання внутрішньої активності, через організацію їі внутрішніх мотиваційних сил, що визначають поведінку $[1,3]$. Конкретні механізми професійного розвитку є індивідуально-своєрідними і відповідають вихідним індивідуальним особливостям. У нашому дослідженні необхідно з'ясувати змістове наповнення поняття “професійна компетентність майбутнього лікаря”. Аналіз змісту визначень понять “компетентність” і “компетенція” доводить нас до розуміння сутності цих понять, яке важливе для побудови моделі компетентного випускника вищого медичного навчального закладу, формування критеріїв оцінювання досягнень студентів, їх готовності до майбутньої діяльності лікаря. Професійна компетентність майбутнього лікаря, на нашу думку, визначається як сформованість діагностичної, клінічної та профілактичної компетентностей. Компоненти професійної компетентності майбутнього лікаря виділялися нами з урахуванням державних та галузевих стандартів медичної освіти: вимог до випускників вищих медичних навчальних закладів; вимог до працівників системи охорони здоров'я; вимог до випускників вищих медичних навчальних закладів в інших країнах світу. Комплексне обгрунтування складових професійної компетентності дозволить, на нашу думку, зоорієнтувати освітньо-кваліфікаційні вимоги майбутніх лікарів до інтеграції освітнього медичного простору європейських держав.

Серед розмаїття структурних компонентів професійної компетентності нами визначено комплекс ключових:

- інформаційні, які визначають способи сприйняття, зберігання і передачі інформації;

- проектувальні, що відображають способи визначення цілей, ресурсів, дій і термінів;

- аналітичні, які включають порівняння, класифікацію, абстрагування, прогнозування, систематизацію і конкретизацію;

- комунікативні, за допомогою яких здійснюється передача інформації, визначається взаємодія, спілкування; 
- соціальні (соціально-професійна позиція і ролі, які виконує фахівець у медичній галузі: лікарординатор, завідувач, керівник та ін.).

Загальноприйнятими факторами формування професійних компетентностей фахівців є соціальні, психологічні й організаційно-педагогічні [3, 5, 6]. До психологічних факторів належать особливості змісту і характеру діяльності особистості як суб'єкта та об'єкта освітнього процесу; рівень готовності до діяльності. Організаційно-педагогічні фактори показують особливості процедури й організації освітнього процесу. Формування професійної компетентності у вищому медичному навчальному закладі будемо розуміти як процес оволодіння стійкими, інтегрованими, системними знаннями з природничо-гуманітарних, фундаментальних та клінічних дисциплін; уміння застосовувати їх у нових, нестандартних ситуаціях; розвиток особисто важливих якостей і професійно важливих властивостей, що забезпечить особистісне станов- лення майбутнього лікаря. Класифікуючи професійні компетентності у групи, ми вибирали ті, які, на наш погляд, при створенні відповідних умов забезпечать особистісне становлення майбутнього лікаря і відповідатимуть усім структурних складовим професійної діяльності лікаря. У структуру професійної компетентності нами включені прогностичний, проективний, когнітивний, організаторський, комунікативний, аналітичний та рефлексивний компоненти.

Висновок. Отже, професійна компетентність майбутнього лікаря - на нашу думку, це теоретична і практична підготовленість студента на основі особистих і професійно важливих якостей; стан сформованості професійних знань, умінь та навичок, ціннісних орієнтацій, культури мовлення, стилю спілкування, аналітичних, прогностичних, проектувальних здібностей, необхідних для виконання діяльності лікаря.

4. Становлення нової моделі надання первинної медико-санітарної допомоги на засадах сімейної медицини в Україні - не данина моді, а об'єктивна реальність / Л. Ф. Матюха, Н. Г. Гойда, В. А. Одринський [та ін.] // Сімейна медицина. - 2013. - № 4. - С. 157-158.

5. Вища медична освіта України на сучасному етапі / В. В. Лазоришинець, М. В. Банчук, О. П. Волосовець [та ін.] // Проблеми сучасної медичної науки та освіти. - 2008. - № 2. - C. 5-10.

6. Ann K. Allen. Research skills for Medical Students / SAGE Publication Inc. - 2012. - P. 264.

7. Dr. John Willison. A handbook for research skills development and assessment in the curriculum / Centre for Learning and Professional Development University of Adelaide. - 2009. - P. 85.

3. Krytska, H.A., Krytskyi, I.O., \& Zahriichuk, H.Ya. (2017). Perspektyvy ta trudnoshchi efektyvnoho vykorystannia innovatsiinykh tekhnolohii dlia zabezpechennia profesiinoi pidhotovky studentiv-medykiv pry vyvchenni klinichnykh dystsyplin [Prospects and difficulties of effective use of innovative technologies for ensuring the professional training of medical students in the studying of clinical disciplines]. Medychna osvita - Medical Education, 2 (74), 33-36 [in Ukrainian].

4. Matiukha, L.F., Hoida, N.H., \& Odrinskyi, V.A. (2013). Stanovlennia novoi modeli nadannia pervynnoi medykosanitarnoi dopomohy na zasadakh simeinoi medytsyny 
v Ukraini - ne danyna modi, a obiektyvna realnist [The formation of a new model of provision of primary health care on the basis of family medicine in Ukraine is not like a fashion, but like an objective reality]. Simeina medytsyna - Family Medicine, 4, 157-158 [in Ukrainian].

5. Lazoryshynets, V.V., Banchuk, M.V., \& Volosovets, O.P. (2008). Vyshcha medychna osvita Ukrainy na suchasnomu etapi [Higher medical education in Ukraine at the present stage]. Problemy suchasnoi medychnoi nauky i osvity -
Problems of Modern Medical Science and Education, 2, 5-10 [in Ukrainian].

6. Enn, K. Allen (2012). Research skills for Medical Students, SAGE Publication Inc., 264.

7. Dzhon Uyillison (2009). A Handbook for Research skills Development and Assessmentin the Curriculum, Centre for Learning and Professional Development Universityof Adelaide.

Електронна адреса для листування: dokter665@gmail.com 